\title{
Mesenteric lymph node cells from neonates present a prominent IL-12 response to CpG oligodeoxynucleotide via an IL-15 feedback loop of amplification
}

Stéphanie Ferret-Bernard ${ }^{1,2}$, Sonia Lacroix-Lamandé ${ }^{1}$, Aude Remot ${ }^{1}$, Coralie Metton ${ }^{1}$, Nelly Bernardet ${ }^{1}$, Bernard Charley ${ }^{3}$, Françoise Drouet ${ }^{1}$, Fabrice Laurent ${ }^{*}$

\begin{abstract}
At birth, the immune system is still in development making neonates more susceptible to infections. The recognition of microbial ligands is a key step in the initiation of immune responses. It can be mimicked to stimulate the immune system by the use of synthetic ligands recognising pattern recognition receptors. In human and mouse, it has been found that neonatal cytokine responses to toll-like receptor (TLR) ligands differ in many ways from those of adults but the relevant studies have been limited to cord blood and spleen cells. In this study, we compared the responses in neonate and adult sheep to CpG oligodeoxynucleotides (ODN), a TLR9 ligand, in both a mucosal and a systemic organ. We observed that in response to CpG-ODN more IL-12 was produced by neonatal than adult sheep cells from mesenteric lymph nodes (MLN) and spleen. This higher IL-12 response was limited to the first 20 days after birth for MLN cells but persisted for a longer period for spleen cells. The major IL12-producing cells were identified as $\mathrm{CD} 14^{+} \mathrm{CD} 11 \mathrm{~b}^{+}$. These cells were poor producers of IL-12 in response to direct stimulation with CpG-ODN and required the cooperation of other MLN cells. The difference in response to CpGODN between neonates and adults can be attributed to both a higher proportion of CD14 $4^{+}$CD $11 b^{+}$cells in neonate lambs and their higher capacity to produce IL-15. The IL-15 increases IL-12 production by an amplifying feedback loop involving CD40.
\end{abstract}

\section{Introduction}

Immune responses in neonates differ from those in adults due to differences in the relative proportions, phenotypes and functional properties of their immune cells [1-4]. In infant and neonate mouse a Th2 bias has been reported that leads to a reduced capacity to respond efficiently to vaccines that rely on a Th1 immune response for their efficacy. Immunoprophylactic strategies have therefore to be adapted for neonates and properly targeted. Pattern recognition receptors are expressed by cells of the innate immune system and identify microbial components or cellular stress. Toll-like receptors (TLR) belong to this family of

\footnotetext{
* Correspondence: laurent@tours.inra.fr

'INRA, UR1282 Infectiologie Animale et Santé Publique, Equipe « Contrôle et Immunologie des Maladies Entériques du Nouveau-Né », Nouzilly, France
} Full list of author information is available at the end of the article receptors, and are attractive targets for immunostimulation strategies; consequently, many synthetic molecules that mimic bacterial or viral components have been generated. Synthetic $\mathrm{CpG}$ oligodeoxynucleotides (CpG-ODN) resembling bacterial DNA have been extensively used to promote Th1 immune responses [5] and to control both systemic and mucosal infections. We observed that a single administration of CpG-ODN to neonate mice can greatly reduce infection by Cryptosporidium parvum [6] by inducing the production IFN $\gamma$, a cytokine central to the control of this zoonotic parasite infecting intestinal epithelial cells $[7,8]$. CpG-ODN have also been shown to be safe to use in veterinary species, $[9,10]$ and effective in ruminants for controlling bacterial [11,12], parasitic [13] and viral infections [14]. The potential of CpG-ODN for stimulating innate immune responses has been also

\section{C) Bïomed Central}


demonstrated in neonate lambs in a study by Nichani et al. reporting that their administration can reduce viral shedding of bovine herpes virus-1 [15].

The specificities of the responses of human and mouse neonatal cells have been described. However, the relevant studies were limited to human cord blood cells and mouse spleen cells. Neonate small ruminants, being much bigger than rodent animal models, allow the recovery of large numbers of cells from various tissues facilitating investigations. In addition, data obtained in human or mouse cannot be directly extrapolated to veterinary species despite the conservation of TLR throughout evolution. This is because TLR responses to their agonists may differ between species due to differential expression among immune cell populations or differences in binding or signalling [16-18]. Exploiting the advantages of a large animal model, the goats, we previously investigated the cytokine response to various TLR ligands of cells isolated from neonatal and adult lymph nodes draining the intestine. The intestine is subjected to many changes after birth due to exposure to dietary antigens and colonization by the commensal flora. In response to TLR stimulation, neonate mesenteric lymph nodes (MLN) cells presented a stronger IFN $\gamma$ and IL-12 response than their adult counterparts [19]. Although $\mathrm{CD}^{+}$lymphocytes were identified as being responsible for the IFN $\gamma$ production, the precise nature of the cells secreting IL-12 was not identified.

Using lambs as a model, we describe further investigations regarding the age-related differences of cytokine responses to TLR ligands. In particular, we aimed to determine until what age neonate MLN and spleen cells continued to produce more IL-12 than their adult counterparts in response to $\mathrm{CpG}-\mathrm{ODN}$ stimulation and the reasons for the difference.

\section{Materials and methods}

\section{Animals and cell isolation}

The Préalpes adult sheep (aged $6 \pm 1$ year), neonates (aged 6 to 14 days) and lambs (aged 20 days) used were reared in conventional but protected sanitary facilities (PFIE, INRA, F-37380 Nouzilly, France). Newborn lambs were not separated from their mothers until one day after birth, to allow them to suckle colostrum. They were then fed ad libitum with reconstituted milk. Experimental protocols were designed in compliance with French law (Décret 2001-464 29/05/ $01)$ and EEC regulations (86/609/CEE) concerning the care and use of laboratory animals. Euthanasia was performed after electric stunning according to AMVA guidelines (2007) on euthanasia. Cells from freshly removed MLN or spleen were isolated as previously described [19].

\section{Reagents}

CpG-2006 5'TCGTCGTTTTGTCGTTTTGTCGTT3' and control-CpG-2006 (Ctl-ODN) 5'TGCTGCTTT'TGTGCTTTTGTGCTT3' have a phosphorothioate backbone and were purchased from Sigma-Aldrich (Lyon, France). Recombinant human TGF $\beta 1$ and recombinant type I interferons (IFN) (IFN $\alpha$ hybrid, constructed with human IFN $\alpha \mathrm{A}$ and $\alpha \mathrm{D}$ is active in all mammalian species) were obtained from AbD Serotec (Oxford, UK). Recombinant human IL-15 was from Immunotools (Friesoythe, Germany). Recombinant ovine IL-12 and IL-10 were kindly provided by S. Wattegedera (Moredun Research Institute, Edinburgh, UK). AntiCD40 mAb supernatant clone ILA156 originally produced by J. Naessens (ILRAD, Nairobi, Kenya) was provided by I. Schwartz-Cornil.

\section{CpG-ODN stimulation and cytokine quantification by ELISA and by bioassay}

Mesenteric lymph node (MLN) or spleen cells were stimulated for $48 \mathrm{~h}$, at a density of $1.5 \times 10^{6} / \mathrm{mL}$ in complete RPMI 1640 medium (Gibco-Invitrogen, Cergy-Pontoise, France) supplemented with 10\% FCS, $100 \mathrm{IU} / \mathrm{mL}$ penicillin, $100 \mu \mathrm{g} / \mathrm{mL}$ streptomycin sulphate and $50 \mu \mathrm{M}$ $\beta$-mercaptoethanol (Merck Chemicals Ltd., Nottingham, UK) with Ctl-ODN $(1 \mu \mathrm{M})$ or CpG-2006 $(1 \mu \mathrm{M})$. In the IL-12 neutralisation assay, mouse anti-bovine IL-12 (clone CC301, Serotec) or its isotype control (mouse IgG2a, Caltag-Invitrogen) was added, at a concentration of $10 \mu \mathrm{g} / \mathrm{mL}$, at the same time as the TLR agonist.

In some experiments, rhTGF $\beta 1$, rovIL-10, rh type I IFN or rhIL-15 was added to MLN cells at the same time as Ctl-ODN or CpG-2006. Culture supernatants were harvested and stored at $-20^{\circ} \mathrm{C}$ until assayed for the detection of cytokines by ELISA. Intracellular staining for IL-12 (clone CC301, AbD Serotec) was performed on MLN cells cultured in complete RPMI medium with Ctl-ODN or CpG-2006 for 25 h. Brefeldin A (Sigma) was added to the cells at a concentration of $5 \mu \mathrm{g} / \mathrm{mL}$, for the last $5 \mathrm{~h}$ of culture.

Pairs of antibodies against bovine cytokines were obtained from AbD Serotec; these antibodies have been shown to recognise ovine IL-12 [20,21], IFN $\gamma$ [21] and IL-10 [20,22]. ELISA was carried out as previously described [19]. Incubations were performed at $37^{\circ} \mathrm{C}$ for IL-10 ELISA and at room temperature for the other ELISA. To assess biologically active TGF $\beta 1$ secretion by ovine cells, we used the TGF $\beta 1$ Emax ${ }^{\circledR}$ ImmunoAssay System (Promega, Charbonnières-les-Bains, France) according to the manufacturer's instructions.

Type I IFN in cell supernatants were quantified using a cytopathic effect reduction assay with Madin-Darby bovine kidney cells challenged with vesicular stomatitis virus. An internal recombinant IFN $\alpha$ reference was 
included as described elsewhere [23]. Each supernatant was tested over eight serial dilutions. Results are expressed as type I IFN units per mL.

\section{Colistin treatment and Gram negative bacterial enumeration}

Control and colistin-treated animals were separated from their mothers directly after birth and bottle-fed every $12 \mathrm{~h}$ for the first day with preheated ewe colostrum containing or not containing $50000 \mathrm{IU} / \mathrm{kg}$ body weight of colistin (Virbac, Carros, France). Thereafter, they were fed daily ad libitum with reconstituted milk containing or not containing $100000 \mathrm{IU} / \mathrm{kg}$ body weight of colistin (Virbac) until the age of 20 days. Mean body weights were used to prepare the milk containing colistin: $3 \mathrm{~kg}$ for 2 - to 8 -day-old, $4 \mathrm{~kg}$ for 9- to 14-day-old and $7 \mathrm{~kg}$ for 15 - to 20-day-old lambs. Lambs were slaughtered at age 20 days and both MLN (for in vitro cell stimulation as previously described) and distal ileum contents were collected. To determine the total number of Gram -ve bacteria, serial dilutions of ileal content homogenised in PBS were plated onto Drigalski lactose agar (selective medium for the isolation of Gram -ve bacteria). The plates were incubated overnight at $37^{\circ} \mathrm{C}$ and colonies counted.

\section{Cell sorting and flow cytometry}

A high-speed MoFlo cell sorter (Dako, Trappes, France) was used to sort freshly isolated total MLN cells. In these experiments, cells were labelled with a mouse antibody specific for ovine CD14 (clone CAM36A, VMRD, Pullman, USA) and stained with a fluorochromeconjugated goat anti-mouse immunoglobulin antibody (Caltag-Invitrogen). Lymph granulocytes in sheep display intermediate levels of CD14 expression [24]. $\mathrm{CD}_{14}{ }^{+}$cell sorting was therefore always performed after gating on non-granulocytic MLN cells according to SSC/ FSC analysis, although most granulocytes were removed on the Histopaque gradient. Both $\mathrm{CD} 14^{+}$and $\mathrm{CD} 14^{-}$cell fractions were cultured in vitro, with $\mathrm{Ctl}-\mathrm{ODN}$ or $\mathrm{CpG}$ 2006, or were directly analysed by qRT-PCR.

For intracellular staining of IL-12, stimulated cells were cultured in the presence of Brefeldin A for the last $5 \mathrm{~h}$. First, the following purified monoclonal antibodies directed against ovine markers were used for surface staining: CD11b (clone MM12A, VMRD), CD14 (clone CAM36A, VMRD), MHC class II (clone 28.1, AbD Serotec) and CD205 (clone CC98, AbD Serotec). Fixed and permeabilised cells were then incubated with the mouse antibovine/ovine IL-12 antibody (clone CC301, AbD Serotec).

\section{Electron microscopy}

Sorted $\mathrm{CD} 14^{+}$cells were fixed, post-fixed, dehydrated in a graded series of ethanol solutions and embedded in
Epon resin (Sigma). Ultrathin sections were cut, stained and examined under a Jeol 1010 transmission electron microscope (Jeol, Croissy-sur-Seine, France).

\section{RNA isolation and real-time RT-PCR}

RNA was extracted with the NucleoSpin RNA II kit (Macherey-Nagel, Hoerdt, France), according to the manufacturer's instructions and quantified using Nanodrop (Thermo Fisher Scientific, Courtaboeuf, France). Purified RNA was reverse-transcribed using oligo(dT) primers and M-MLV reverse transcriptase (Promega). Primer pairs were designed using Primer 3 software (Additional file 1, Table S1). Each primer was designed on different exons to span the intervening intron and thus avoid amplification from contaminating genomic DNA. For each primer pair, all qPCR displayed an efficiency of between $90 \%$ and $110 \%$. Diluted cDNA was combined with primers and IQ SYBRGreen Supermix (Bio-Rad, Hercules, USA) according to the manufacturer's recommendations and real-time assays were run on a Bio-Rad Chromo 4 (Bio-Rad). The specificity of the qPCR reactions was assessed by analysing the melting curves of the products and size verification of the amplicons. To minimise sample variations, we used identical numbers of cells and high quality RNA. Hypoxanthine phosphoribosyltransferase (HPRT) mRNA levels were used to normalise RNA quantification.

\section{Statistical analyses}

Non-parametric Mann-Whitney (two groups) and Kruskal-Wallis (three or more groups) statistical tests were used to compare unpaired values. In case of paired values, paired $t$-tests were performed.

\section{Results}

IL-12 and IFN $\gamma$ responses of neonatal and adult MLN cells to CpG-ODN stimulation

Neonatal MLN cells stimulated in vitro with CpG-2006 produced variable but significantly larger amounts of IL12 (Figure 1A) and IFN $\gamma$ (Figure 1B) than adult MLN cells. This higher IL-12 response was also observed for neonatal spleen cells (Figure 1C). Adult MLN and spleen effector cells ( $\mathrm{T}$ cells and NK cells) were not intrinsically impaired for IFN $\gamma$ production compared to neonatal cells, as they produced significantly larger amounts of this cytokine in response to non-specific stimulation in vitro with phorbol myristate acetate associated with ionomycin (data not shown). Neutralisation of IL-12 in vitro indicated that the higher production of IFN $\gamma$ by neonatal MLN cells was due in large part to the higher level of IL-12 released upon CpG-2006 stimulation (Figure 1D, $78 \pm 12 \%$ inhibition, $\mathrm{p}<0.005$ ). We therefore investigated the particular features of the neonatal cells producing IL-12 in response to CpG-2006. 

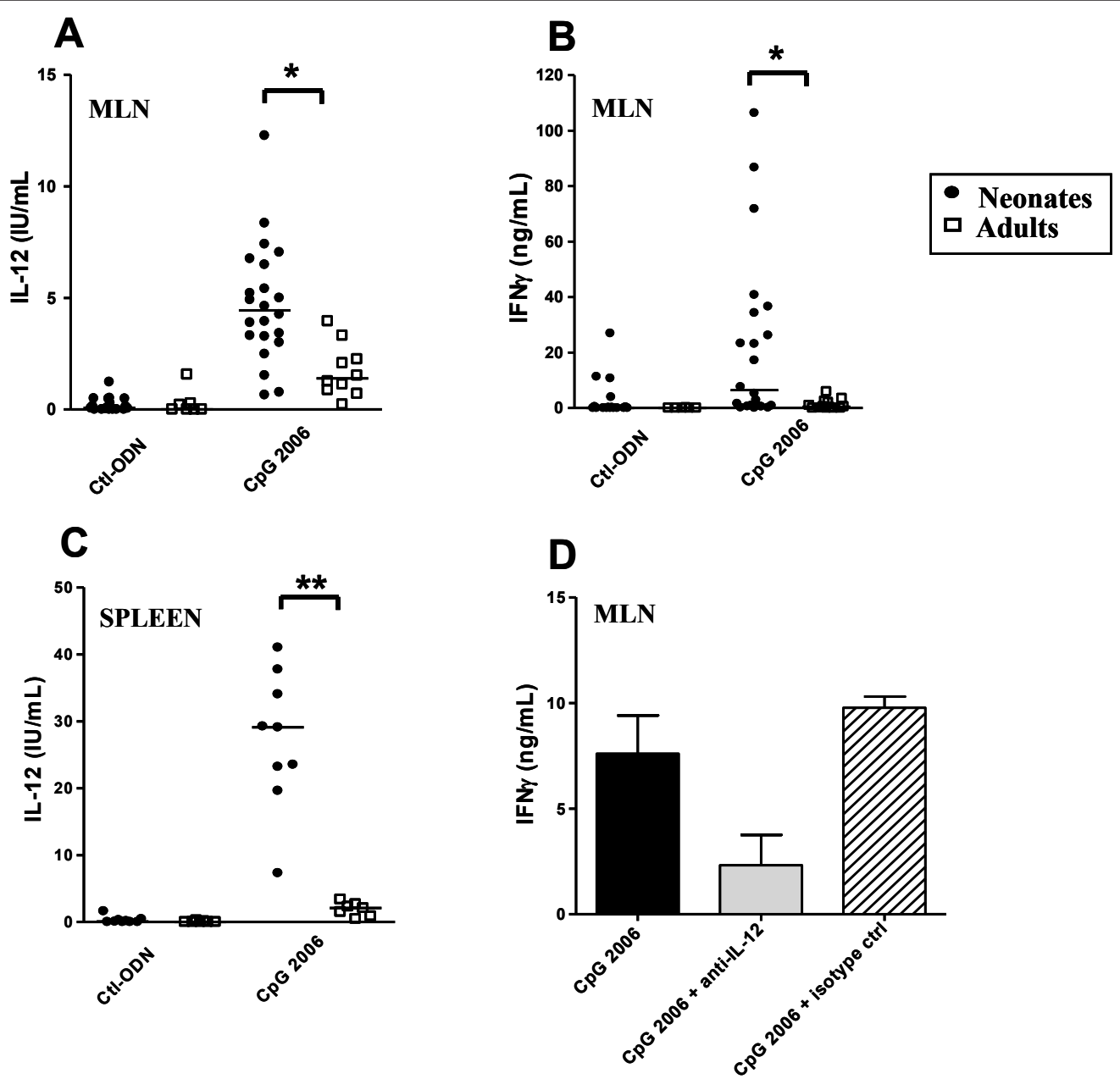

Figure 1 Comparative IL-12 and IFN $\gamma$ responses of neonatal and adult cells following TLR agonist stimulation. Neonatal and adult MLN (A, B) and spleen cells (C) were cultured in vitro with $1 \mu \mathrm{M}$ Ctl-ODN or $1 \mu \mathrm{M} \mathrm{CpG-2006.} \mathrm{Supernatants} \mathrm{were} \mathrm{harvested} \mathrm{after} 48 \mathrm{~h}$ of culture and ELISA was carried out for IL-12 (A, C) and IFNy (B) secretions. (D) Mouse anti-bovine IL-12 (grey bar) or its isotype control (hatched bar) was added to neonatal MLN cells, at the same time as CpG-2006 or CtI-ODN. IFN $\gamma$ secreted into the culture supernatants was determined after $48 \mathrm{~h}$. The mean \pm SEM concentration of IFN $\gamma$ secretion is shown $\left(C p G-2006-\right.$ Ctl-ODN). ${ }^{*} p \leq 0.005 ;{ }^{* *} p \leq 0.001$.

Age-dependent IL-12 responses of MLN and spleen cells to CpG-ODN stimulation

We first studied the evolution with age of the stronger response in vitro of neonatal cells. We measured IL-12 secretion by MLN and spleen cells from 20-day-old lambs, neonates and adults. IL-12 secretion by MLN cells in response to in vitro CpG-2006 stimulation rapidly decreased with age: cells from 20-day-old lambs producing as little IL-12 as adult cells (Figure 2A). By contrast, splenocytes from 20-day-old animals, like neonatal cells, secreted significantly larger, albeit variable, amounts of IL-12 than adult cells (Figure 2B). Thus, the higher IL-12 response began to decline earlier in MLN cells than in spleen cells, suggesting major changes in TLR responsiveness in the lymph nodes within the first few days of life.
Effect of Gram negative intestinal flora on the response of neonatal MLN cells to CpG-ODN

The decrease of IL-12 secretion between 14 and 20 days after birth could be related to progressive installation of the intestinal microflora. Gram -ve commensal bacteria have a large impact on the formation of intestinal lymphoid tissues and the establishment of gut homeostasis in mice [25]. To assess the possible role of Gram -ve bacteria colonisation in our model, lambs were fed with milk supplemented with the antibiotic colistin from birth to 20 days of age. The Gram -ve bacterial count in the distal ileal content of these animals was at least 4 log lower than in controls (Figure 3A) but IL-12 response to CpG-2006 was not significantly different (Figure $3 \mathrm{~B}$ ). This suggests that another mechanism was responsible for the higher IL-12 secretion by neonatal MLN cells upon TLR ligation. 


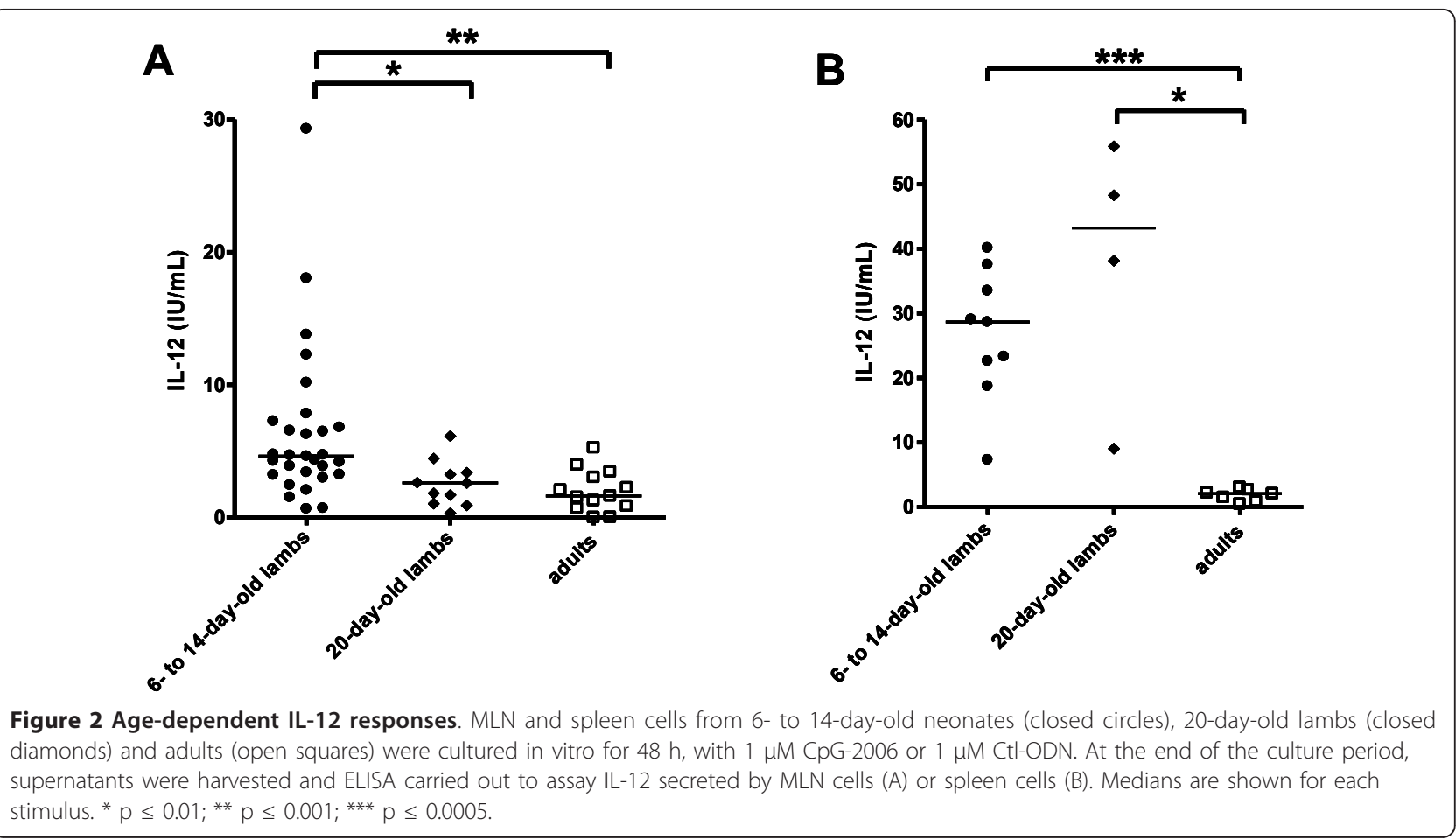

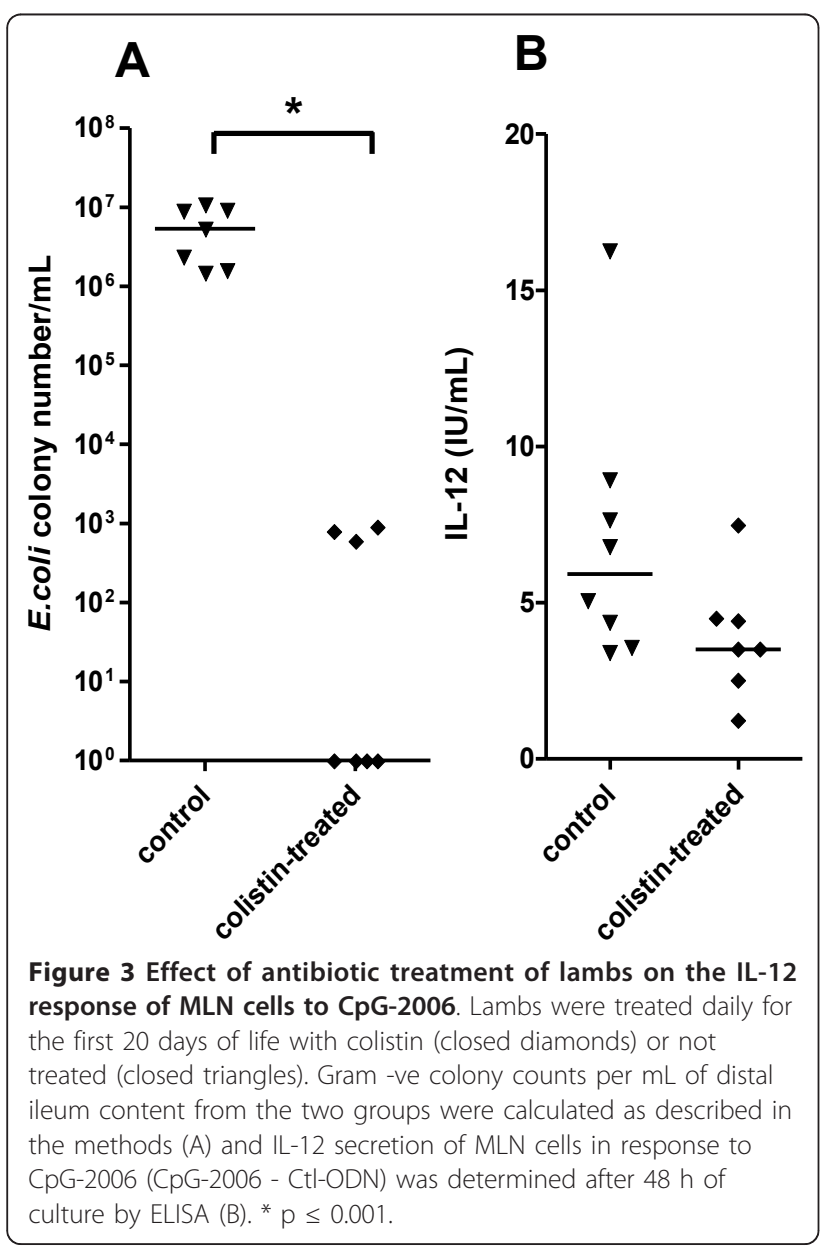

IL-12-producing cells among lamb bulk MLN cells

We aimed to identify the major IL-12 secreting cell population to characterise more precisely the mechanisms governing the differences between neonates and adults. ELISA kinetic assays showed that IL-12 secretion started between 6 and $20 \mathrm{~h}$ following CpG stimulation and that the secretion doubled between $20 \mathrm{~h}$ and $28 \mathrm{~h}$ post-stimulation (Figure 4A). We stained neonatal MLN cells for intracellular IL-12 at $20 \mathrm{~h}$ post-stimulation. The bar graph (Figure 4B) displays the percentage of IL-12 secreting cells among CD11b, CD14, MHC class II and CD205 positive cells. CD14 ${ }^{+}$cells but also $\mathrm{CD}_{11 \mathrm{~b}^{+} \text {cells }}$ were major contributors to IL-12 secretion in response to $\mathrm{CpG}$. Flow cytometry analysis showed that most of the $\mathrm{CD} 14^{+}$cells co-expressed CD11b. Moreover, all $\mathrm{CD}_{11 \mathrm{~b}^{+}}$cells co-expressed CD14 (data not shown). We therefore decided to focus our study on CD14 ${ }^{+}$cells. Transmission electron microscopy revealed that neonatal CD $14^{+}$MLN cells had numerous processes and horseshoe-shaped nuclei, as expected for cells of the myeloid lineage (Figure 4C). We also observed several dark electron-dense granules and a well developed endosomal compartment resembling that of ovine monocytederived dendritic cells (DC) [26] and a CD11b ${ }^{\text {int } / \text { high }}$ subpopulation of bone marrow-derived DC [27].

CD14 ${ }^{+}$and CD14 cells purified by flow cell sorting from neonate and adult MLN were stimulated with CpG-2006. The absence of CD14 ${ }^{+}$cells inhibited greatly IL-12 secretion not only in neonate $(67 \pm 7 \%)$ but also in adult $(85 \pm 8 \%)$ samples, indicating the essential role 

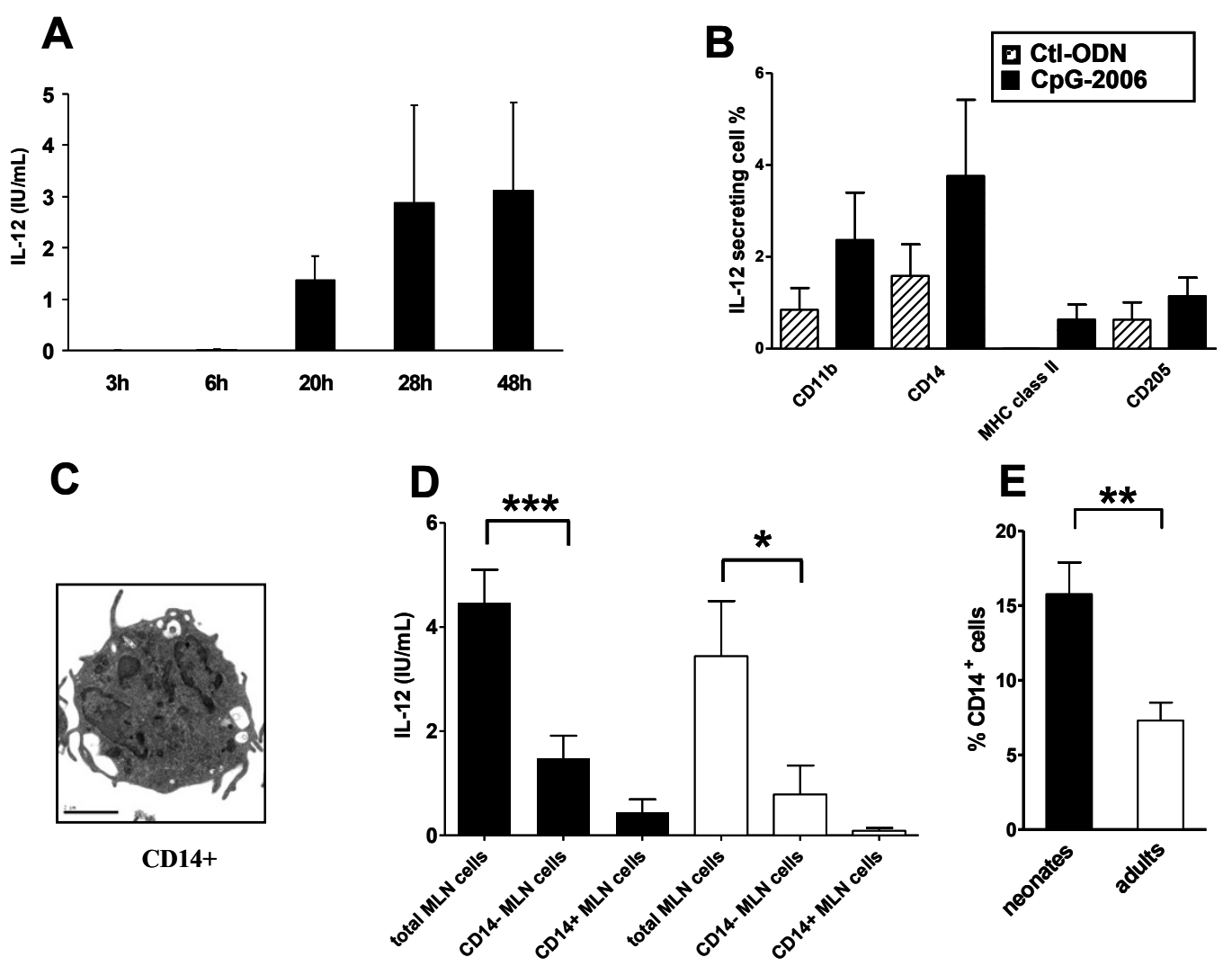

Figure 4 Characterisation of IL-12-producing cells. Kinetics of the IL-12 response to CpG-2006 during the first $48 \mathrm{~h}$ was followed by ELISA. Mean \pm SEM IL-12 secretion (CpG-2006-CtI-ODN) is shown for each time point. Means \pm SEM were calculated from three independent experiments (three different neonates) giving similar results (A). Neonatal MLN cells were cultured in vitro with $1 \mu \mathrm{M}$ Ctl-ODN (hatched bars) or 1 MM CpG-2006 (black bars) for 25 h, with brefeldin A added for the last 5 h. IL-12 intracellular staining was combined with labelling of CD11b, CD14, MHC class II and CD205. Values reported are means \pm SEM from three independent experiments (three different neonates) giving similar results (B). Neonatal CD14 $\mathrm{MLN}$ cells were observed by transmission electron microscopy. The scale bar on the representative picture indicates $2 \mu \mathrm{m}$ (C). Neonatal ( $n=11$, closed bars) and adult ( $n=6$, open bars) total MLN cells and sorted CD14 cells and CD14 ${ }^{+}$cells $(n=6$ for neonates and $\mathrm{n}=5$ for adults) were stimulated for $48 \mathrm{~h}$ with $1 \mu \mathrm{M}$ CpG-2006 or $1 \mu \mathrm{M}$ CtI-ODN and ELISA was used to assay secreted IL-12 (CpG-2006 Ctl-ODN) (D). Mean \pm SEM of CD14+ cell proportions in 6- to 14-day-old neonatal $(n=27$, closed bar) and adult $(n=13$, open bar) total MLN cells were assessed by single staining and flow cytometry $(E) .{ }^{*} p \leq 0.05 ;{ }^{* *} p \leq 0.01 ;{ }^{* *} p \leq 0.001$.

of these cells in both groups (Figure 4D). Some CD14cells participated in the residual IL-12 secretory activity $(33 \pm 7 \%)$ in neonates and $(15 \pm 8 \%)$ in adults. We cultured the same numbers of neonate or adult sorted $\mathrm{CD}_{14}{ }^{+}$cells in the presence of $\mathrm{CpG}$ for $48 \mathrm{~h}$ but very little or no IL-12 was detected. Therefore, CD14 ${ }^{+}$are poor IL-12-producing cells in the absence of CD14cells, suggesting an indirect activation mechanism (Figure 4D). Flow cytometry analyses also revealed that the proportion of $\mathrm{CD} 14^{+}$cells among bulk MLN cells was twice as high in neonates as in adults (Figure 4E). Although we did not observe a direct correlation between the proportion of $\mathrm{CD} 14^{+}$cells in the MLN and the IL-12 response to CpG-2006 (data not shown), this quantitative difference may nevertheless contribute to the higher responsiveness of neonatal MLN cells to CpG-ODN.
Effects of TGF $\beta 1$, IL-10 and type I IFN on the cytokine response to CpG-ODN

Immune cells in the intestinal mucosa are conditioned by many regulatory cytokines, including TGF $\beta 1$ and IL-10, helping to avoid responses against commensal flora and dietary antigens. Booth et al. observed the presence of regulatory $B$ cells producing large amounts of IL-10 in sheep Peyer's patches and downregulating TLR9-induced cytokine responses [28]. Therefore, we tested the effect of rhTGF $\beta 1$ and rovIL-10, during CpGODN stimulation, on the IL-12 response of adult and neonate MLN cells. TGF $\beta 1$ and IL-10 each strongly inhibited IL-12 release in both neonates and adults (Figures $5 \mathrm{~A}, \mathrm{~B})$. At some concentrations, IL-12 secretions in response to CpG from adult MLN cells were significantly more sensitive than neonate MLN cells to these regulatory cytokines. This may result from a higher 


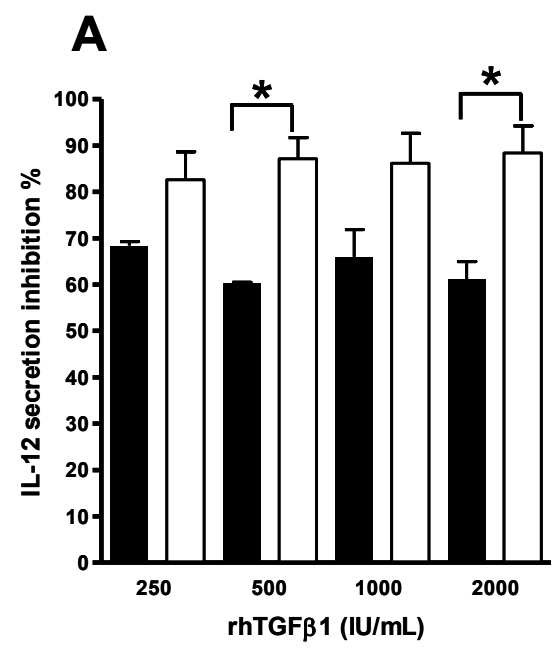

C
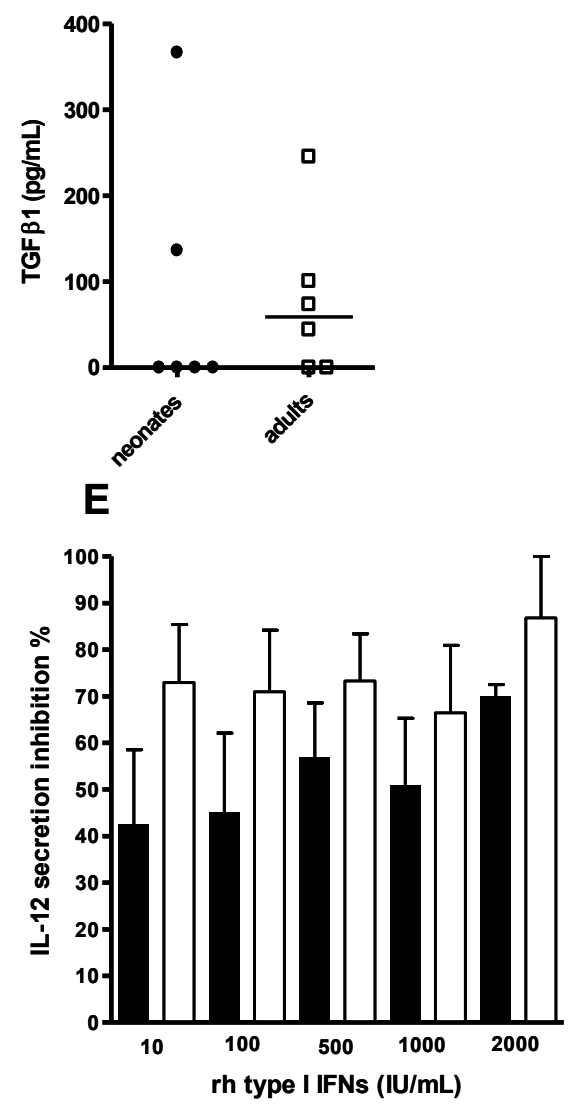

B

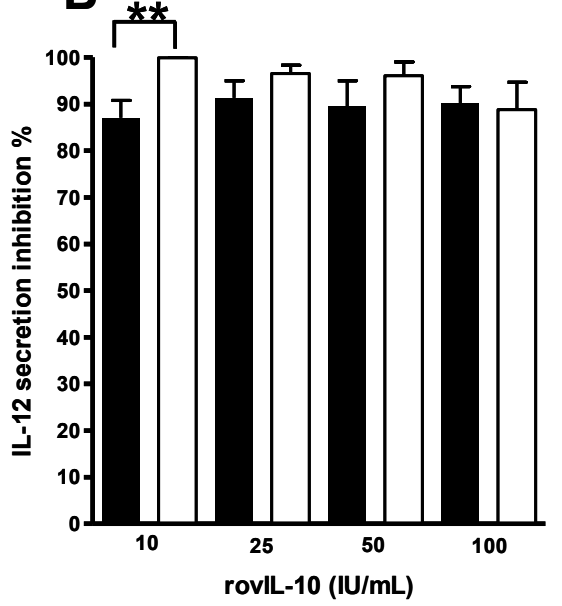

D

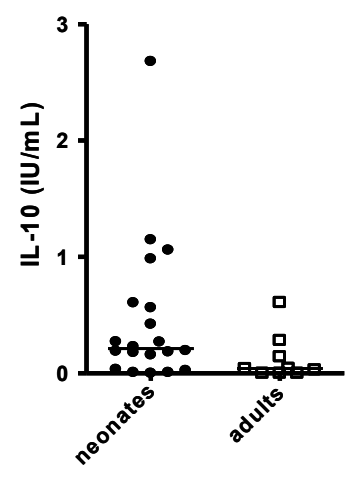

$\mathbf{F}$

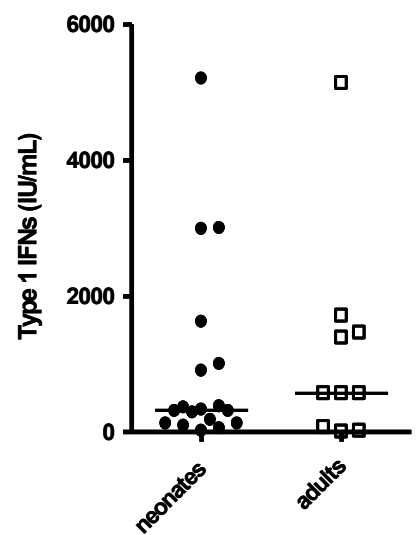

Figure 5 Effect of regulatory cytokines on the IL-12 response to CpG-2006. MLN cells from neonates ( $n=3-5$, closed bars) and adults ( $n=$ $5-7$, open bars) were stimulated in vitro for $48 \mathrm{~h}$ with $1 \mu \mathrm{M}$ of $\mathrm{CpG}-2006$ or $1 \mu \mathrm{M}$ of Ctl-ODN in the presence of each of various amounts of rhTGF 1 (A), rovIL-10 (B) and rh type I IFN (E) and IL-12 secreted by MLN was assayed by ELISA (CpG-2006 - CtI-ODN). The percentage of IL-12 secretion inhibition is shown for each dose of recombinant cytokine. MLN cells from neonates (closed circles) and adults (open squares) were cultured in vitro for $48 \mathrm{~h}$, with $1 \mu \mathrm{M}$ CpG-2006 or $1 \mu \mathrm{M}$ of CtI-ODN. TGF 1 (C) and IL-10 (D) production was measured by ELISA and type I IFN activity by bioassay (F). Plot values were calculated by subtracting the values for Ctl-ODN stimulated cells from those for CpG-2006 stimulated cells. Medians are indicated for each group. ${ }^{*} p \leq 0.05 ;{ }^{* *} p \leq 0.005$. 
expression of the TGF $\beta 1$ and IL-10 receptors on adult MLN cells compared to those of neonates and/or from intracellular signalling differences. Possibly, regulatory $\mathrm{T}$ cells, producing TGF $\beta 1$ and IL-10, are more numerous among adult MLN cells, explaining the lower overall IL-12 secretion by total MLN cells. However, analysis of FoxP3 mRNA expression by MLN cells was not consistent with this possibility, as the expression level was similar in neonatal and adult samples (data not shown). Besides, no significant differences related to the secretion of these two regulatory cytokines following $\mathrm{CpG}$ stimulation were observed between neonates and adults (Figures 5C, D). However, when TGF $\beta 1$ secretion was detected in response to CpG-ODN, it may have affected preferentially the IL-12 response of adult animals.

We next searched for differences that may affect the signal provided by CD14 cells to $\mathrm{CD} 14^{+}$cells for IL-12 production. It has been reported that type I IFN either stimulate or inhibit IL-12 production by myeloid cells [29,30]. TLR9-triggering of plasmacytoid DC (pDC) induces the secretion of large amounts of type I IFN [31]. We investigated exactly how type I IFN influence IL-12 secretion by CD $14^{+}$MLN from neonates and adults stimulated by CpG-2006. Interestingly, rhIFN (IFN $\alpha$ hybrid) displayed suppressive properties on both neonate and adult MLN cells (Figure 5E). We performed a type I IFN bioassay on supernatants from neonate and adult MLN cells after CpG-2006 stimulation to test whether the lower IL-12 response in adults was associated with higher levels of type I IFN, but no difference in type I IFN concentrations were observed (Figure 5F).

\section{Role of IL-15 in the IL-12 response of MLN cells to CpG- ODN}

A feedback loop of amplification has been described for IL-15 in the IL-12 response to CpG-ODN involving CD40/CD40L interaction [32]. As no ELISA is yet available for sheep IL-15, we studied its mRNA by quantitative RT-PCR. qRT-PCR with MLN cells stimulated with CpG showed that IL-15 mRNA was much more abundant in neonatal cells than in their adult counterparts, from $3 \mathrm{~h}$ to $20 \mathrm{~h}$ after stimulation with a kinetic of expression similar to that of the IL-12/23p40 chain (Figures 6A, 6B). To identify the main source of IL-15producing cells we analysed IL-15 mRNA in $\mathrm{CD}_{14}^{+}$and CD14- cells from neonates activated with CpG-2006: IL15 mRNA was more abundant in $\mathrm{CD}_{14}{ }^{+}$cells (Figure $6 \mathrm{C})$. To test that IL-15 can potentiate IL-12 secretion in adult MLN cells, we added rhIL-15 at the same time as CpG and the result was an IL-12 secretion that was about three-fold higher than in the controls (Figure 6D). We next analyzed the involvement of CD40 in the IL-12 production by adding an anti-CD40 mAb concomitantly with IL-15 and CpG-2006 to adult MLN cell culture.
CD40 binding by the antibody reduced by $51 \pm 19 \%$ the IL-12 response relative to the isotype control $\mathrm{mAb}$ (Figure 6E). This suggests that CD40 binding by the $\mathrm{mAb}$ limits its interaction with its ligand.

\section{Discussion}

Neonates are more sensitive to infections in particular when exposed to poor sanitary conditions before their immune system is fully developed. It is therefore important to develop immunoprophylactic strategies dedicated to neonates. With the discovery of TLRs and their importance in the initiation of immune responses to invading pathogens, a large set of new synthetic adjuvants has been developed including CpG-ODN for use against infectious disease and cancer [33-35]. In human and mouse, the age-dependent response to TLR has only been documented in cord blood cells and spleen cells, respectively [36-38]. The size of small ruminants facilitates investigation of these responses in different organs including mucosal tissues and their draining lymph nodes $[19,28]$.

Here, we report that cells isolated from the MLN and spleen in neonate lambs produced more IL-12 than their equivalents in adults in response to CpG-2006. This higher IL-12 production was responsible in large part for the higher IFN $\gamma$ response in neonatal stimulated MLN cells as revealed by in vitro IL-12 neutralisation assay. We next examined the age until which neonate cells produced more IL-12 than adults and found that this stronger IL-12 response was restricted to about the first two weeks of life: from age 20 days MLN from lambs produced similar amounts of IL-12 as those from adults. Interestingly, spleen cells from 20-day-old lambs continued to produce more IL-12 in response to CpGODN suggesting that a rapid and specific change in TLR agonist responsiveness occurs in MLN. During this period, the dietary regimen of lambs was similar with reconstituted milk provided ad libitum. As MLN drain the intestinal tissue, we thought that the progressive installation of the commensal flora might have influenced TLR9 responsiveness. Indeed, Gram -ve bacteria are important for lymphoid tissue development [25]. We set up a protocol to control Gram -ve bacteria by feeding lambs with reconstituted milk containing the antibiotic colistin. Although dramatically reducing Gram -ve bacterial counts in the intestine of 20-day-old lambs, this treatment did not significantly affect the capacity of MLN cells to produce IL-12. We next investigated the role of regulatory cytokines, including IL-10 and TGF $\beta 1$ produced in large amounts in intestinal tissue. These cytokines effectively suppressed IL-12 production by MLN cells stimulated with CpG-2006. Although, in response to CpG-2006 stimulation in vitro, they were produced in similar amounts by MLN cells whatever the 

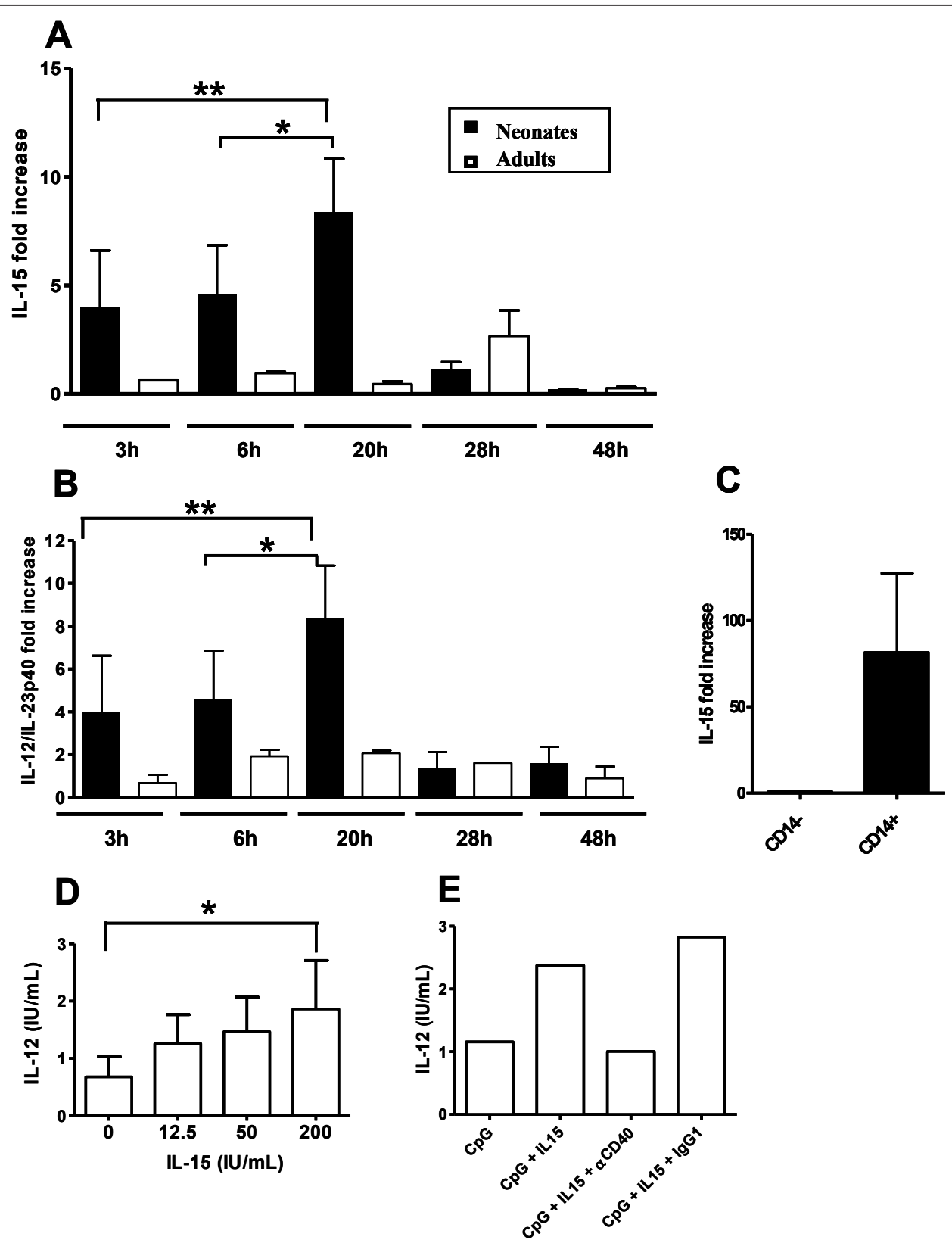

Figure 6 Role of IL-15 in the IL-12 response of MLN cells to CpG-2006. The kinetics of IL-15 (A) and IL-12/IL-23p40 (B) mRNA production in response to CpG-2006 was determined by quantitative RT-PCR. Experiments were performed with MLN cells isolated from three neonates and three adults. $20 \mathrm{~h}$ post-stimulation, MLN cells isolated from three different neonates were recovered and sorted into CD14- and CD14 ${ }^{+}$cell subsets and IL-15 mRNA was assayed by quantitative RT-PCR in each subset (C). After normalisation with the reference gene (HPRT), the RT-PCR data are reported as means \pm SEM values of the ratio of CpG-2006 stimulated to Ctl-ODN stimulated cells (A, B, C). MLN cells, isolated from eight adults, were stimulated with CpG-2006 for $48 \mathrm{~h}$, with or without various amounts of rhIL-15; secreted IL-12 was measured by ELISA (D). The mean \pm SEM level of IL-12 secretion is shown for each dose of recombinant cytokine (CpG-2006 - Ctl-ODN). Adult MLN cells were stimulated with CpG-2006 (or Ctl-ODN) and $200 \mathrm{IU} / \mathrm{mL}$ of IL-15 in the presence of anti-CD40 mAb or its isotype control and IL-12 was quantified by ELISA $48 \mathrm{~h}$ later (CpG-2006 - Ctl-ODN). Data are from one representative animal of five, all giving similar results (E). ${ }^{*} p<0.05 ;{ }^{* *} p<0.005$.

age of the animal and only detected for some animals. Adult MLN cells activated with CpG-ODN presented a slightly higher sensitivity to these cytokines at certain concentrations. Therefore we cannot exclude that for some animals it may participate to the lower IL-12 response of adults. Booth et al. [28] identified a CD5 $\mathrm{CD} 21^{+} \mathrm{B}$ cell population in the ileal Peyer's patches (iPP) in adult sheep. These cells reduce the expression of IFN $\gamma$ and IL-12 by iPP cells stimulated with CpGODN by producing large amount of IL-10. However, in 
agreement with our results the authors did not observe any similar regulatory mechanism in the MLN [28]. To continue, we needed to identify the cell population responsible for IL-12 production. Intracellular IL-12 staining revealed that cells expressing CD14 and CD11b were the main producers. These cells have a dendritic morphology and resemble sheep bone marrow-derived DC [26,27]. Possibly, these myeloid cells originate from blood monocytes and differentiate into inflammatory DC. These DC are known to produce abundant IL-12 and potently stimulate Th1 responses [39]. We observed that the percentage of CD14 $4^{+}$cells was higher in MLN of neonates than of adults. This might contribute to the higher IL-12 response of neonate MLN but we did not observe a direct correlation between the percentage of CD $14^{+}$cells in MLN and the level of IL-12 produced after CpG stimulation; consequently, we do not think that this is the complete explanation. CD $14^{+}$cells respond poorly to direct $\mathrm{CpG}-2006$ stimulation but require the cooperation of other cells to release IL-12. It has been reported that Mycobacterium bovis-induced IL12 secretion by bovine $\mathrm{DC}$ is enhanced by $\mathrm{WC}^{+} \gamma \delta \mathrm{T}$ cells [40]. Moreover, Hedges et al. observed that bovine $\gamma \delta \mathrm{T}$ cells express different TLR including TLR9 and respond directly to some pathogen-associated molecular patterns like LPS and peptidoglycan, however in this study the response of $\gamma \delta$ T cells to CpG-ODN was not investigated [41]. Therefore in our experimental model $\gamma \delta \mathrm{T}$ cells may cooperate with $\mathrm{CD} 14^{+}$cells for the IL-12 response to $\mathrm{CpG}-\mathrm{ODN}$. Another population, $\mathrm{pDC}$ have been shown to cooperate with the IL-12 response of conventional DC (cDC) to CpG-ODN [42]. Activated pDC produce alpha IFN, cytokines that in our experimental model inhibited the IL-12 response of MLN cells stimulated with CpG-2006. After stimulation, we found only a low level of type I IFN activity. This is probably because CpG-2006 is a class B-ODN and this class induces type I IFN much more weakly than do class A- and class CODN. However, the level of type I IFN activity released by neonates and adults being equivalent, this cannot explain the difference in IL-12 production observed. Kuwajima et al. showed that CpG-treated IL-15-deficient mice produced little IL-12 [32]. They observed that CpGstimulated $\mathrm{CDC}$ were the main producers of both IL-15 and IL-12, but CDC did not produce IL-12 in the absence of pDC. After CpG-2006 stimulation, we observed a much stronger concurrent upregulation of IL-12p40 and IL-15 mRNA in MLN cells from neonate than adult sheep suggesting that in adults IL-15 availability may be insufficient for the full activation. We therefore added exogenous IL-15 to CpG-stimulated adult MLN cell and observed an increase in IL-12 production of up to a three-fold. When a CD40 mAb was added to the culture medium, it reduced IL-12 production by half. This is consistent with the findings of Kuwajima et al. [32] who observed that IL-15-induced CD40 expression by cDC and interaction between CD40 on $\mathrm{CDC}$ and CD40 ligand on $\mathrm{pDC}$ led to IL-12 production by $\mathrm{CDC}$. IL-15 therefore plays a key role in the innate response to $\mathrm{CpG}$ and seems to act via a feedback amplification loop. We recently demonstrated that IL-15 is also an important molecule for NK cells in neonates, another innate immune cell population [3]. Indeed, NK cells from one week-old neonate calves expanded in presence of IL-15, but not IL-2, presented both a higher cytotoxicity than their equivalents from older animals in direct lysis assay and a higher IFN $\gamma$ response to IL-12 when associated with NKp46 receptor stimulation.

Here, we demonstrate the potential of CpG-ODN to induce a preferential Th1-type cytokine and IL-15 response in neonate lambs. $\mathrm{CpG}$ oligonucleotides are therefore potentially useful molecules for enhancing the efficacy of vaccines against intracellular pathogens affecting these animals.

\section{Additional material}

Additional file 1: List of primers used for qRT-PCR analysis. Table showing complete list of primer pairs used for qRT-PCR analysis.

\section{Acknowledgements}

We would like to thank T Chaumeil and E Guitton for supplying us with animals and for helping us with the neonates and during the antibiotic treatment protocol. We would also like to thank $Y$ Le Vern for expert technical assistance with cell sorting and A Brée for her help with bacteriology procedures. We are grateful to $S$ Wattegedera for providing recombinant ovine cytokines, which were produced at the Moredun Research Institute with funding from the Scottish Executive Environment and Rural Affairs Department (SEERAD) in collaboration with the BBSRC/ SEERAD Immunological Toolbox initiative. We are thankful to I SchwartzCornil (INRA Jouy-en-Josas) for providing anti CD40 mAb supernatant originally produced by J Naessens (ILRAD, Nairobi, Kenya).

\section{Author details}

'INRA, UR1282 Infectiologie Animale et Santé Publique, Equipe " Contrôle et Immunologie des Maladies Entériques du Nouveau-Né », Nouzilly, France. ${ }^{2}$ INRA, UMR 1079 Systèmes d'Elevage, Nutrition Animale et Humaine, Equipe "Nutrition périnatale et adaptabilité intestinale », Saint Gilles, France. ${ }^{3}$ INRA, UR0892 Unité Virologie et Immunologie Moléculaires, Jouy-en-Josas, France.

\section{Authors' contributions}

SFB conceived and designed the experiments, performed the experiments and the statistical analysis and wrote the manuscript. SLL performed experiments and the statistical analysis and corrected the manuscript. AR performed experiments. CM and NB performed the RNA isolation and real time RT-PCR experiments. BC carried out the type I IFN bioassays. FD performed the experiments. FL conceived, designed, performed and coordinated the experiments and wrote the manuscript. All authors read and approved the final manuscript.

\section{Competing interests}

The authors declare that they have no competing interests.

Received: 2 August 2010 Accepted: 30 September 2010 Published: 2 February 2011 


\section{References}

1. Levy O, Suter EE, Miller RL, Wessels MR: Unique efficacy of Toll-like receptor 8 agonists in activating human neonatal antigen-presenting cells. Blood 2006, 108:1284-1290.

2. Zhao J, Kim KD, Yang X, Auh S, Fu YX, Tang H: Hyper innate responses in neonates lead to increased morbidity and mortality after infection. Proc Natl Acad Sci USA 2008, 105:7528-7533.

3. Elhmouzi-Younes J, Storset AK, Boysen P, Laurent F, Drouet F: Bovine neonate natural killer cells are fully functional and highly responsive to interleukin-15 and to NKp46 receptor stimulation. Vet Res 2009, 40:54.

4. Lacroix-Lamandé S, Rochereau N, Mancassola R, Barrier M, Clauzon A, Laurent F: Neonate intestinal immune response to $\mathrm{CpG}$ oligodeoxynucleotide stimulation. PLoS One 2009, 4:e8291

5. Krieg AM: CpG motifs in bacterial DNA and their immune effects. Annu Rev Immunol 2002, 20:709-760.

6. Barrier M, Lacroix-Lamandé S, Mancassola R, Auray G, Bernardet N, Chaussé AM, Uematsu S, Akira S, Laurent F: Oral and intraperitoneal administration of phosphorothioate oligodeoxynucleotides leads to control of Cryptosporidium parvum infection in neonatal mice. J Infect Dis 2006, 193:1400-1407.

7. Theodos CM, Sullivan KL, Griffiths JK, Tzipori S: Profiles of healing and nonhealing Cryptosporidium parvum infection in C57BL/6 mice with functional $B$ and $T$ lymphocytes: the extent of gamma interferon modulation determines the outcome of infection. Infect Immun 1997, 65:4761-4769.

8. Lacroix-Lamandé S, Mancassola R, Naciri M, Laurent F: Role of gamma interferon in chemokine expression in the ileum of mice and in a murine intestinal epithelial cell line after Cryptosporidium parvum infection. Infect Immun 2002, 70:2090-2099.

9. Ioannou XP, Griebel P, Mena A, Gomis SM, Godson DL, Mutwiri G, Hecker R, Babiuk LA, van Drunen Littel-van den Hurk S: Safety of CpG oligodeoxynucleotides in veterinary species. Antisense Nucleic Acid Drug Dev 2003, 13:157-167.

10. Mutwiri G, Pontarollo R, Babiuk S, Griebel P, van Drunen Littel-van den Hurk S, Mena A, Tsang C, Alcon V, Nichani A, loannou X, Gomis S, Townsend $H$, Hecker R, Potter A, Babiuk LA: Biological activity of immunostimulatory CpG DNA motifs in domestic animals. Vet Immunol Immunopathol 2003, 91:89-103.

11. Wedlock DN, Skinner MA, de Lisle GW, Vordermeier HM, Hewinson RG, Hecker R, an Drunen Littel-van den Hurk S, Babiuk LA, Buddle BM: Vaccination of cattle with Mycobacterium bovis culture filtrate proteins and CpG oligodeoxynucleotides induces protection against bovine tuberculosis. Vet Immunol Immunopathol 2005, 106:53-63.

12. Zhu YM, Miao JF, Zhang YS, Li Z, Zou SX, Deng YE: CpG-ODN enhances mammary gland defense during mastitis induced by Escherichia coli infection in goats. Vet Immunol Immunopathol 2007, 120:168-176.

13. Graham SP, Saya R, Awino E, Ngugi D, Nyanjui JK, Hecker R, Taracha EL, Nene V: Immunostimulatory CpG oligodeoxynucleotides enhance the induction of bovine CD4+ cytotoxic T-lymphocyte responses against the polymorphic immunodominant molecule of the protozoan parasite Theileria parva. Vet Immunol Immunopathol 2007, 115:383-389.

14. Mapletoft JW, Oumouna M, Townsend HG, Gomis S, Babiuk LA, van Drunen Littel-van den Hurk S: Formulation with CpG oligodeoxynucleotides increases cellular immunity and protection induced by vaccination of calves with formalin-inactivated bovine respiratory syncytial virus. Virology 2006, 353:316-233.

15. Nichani AK, Mena A, Kaushik RS, Mutwiri GK, Townsend HG, Hecker R, Krieg $A M$, Babiuk LA, Griebel PJ: Stimulation of innate immune responses by CpG oligodeoxynucleotide in newborn lambs can reduce bovine herpesvirus-1 shedding. Oligonucleotides 2006, 16:58-67.

16. Rehli M: Of mice and men: species variations of Toll-like receptor expression. Trends Immunol 2002, 23:375-378.

17. Edwards AD, Diebold SS, Slack EM, Tomizawa H, Hemmi H, Kaisho T, Akira S, Reise Sousa C: Toll-like receptor expression in murine DC subsets: lack of TLR7 expression by CD8 alpha+ DC correlates with unresponsiveness to imidazoquinolines. Eur J Immunol 2003, 33:827-833.

18. Werling $D$, Jungi TW: TOLL-like receptors linking innate and adaptive immune response. Vet Immunol Immunopathol 2003, 91:1-12.

19. Tourais-Esteves I, Bernardet N, Lacroix-Lamande S, Ferret-Bernard S, Laurent F: Neonatal goats display a stronger TH1-type cytokine response to TLR ligands than adults. Dev Comp Immunol 2008, 32:1231-1241.
20. Wattegedera S, Sills K, Howard CJ, Hope JC, Mclnnes CJ, Entrican G: Variability in cytokine production and cell proliferation by mitogenactivated ovine peripheral blood mononuclear cells: modulation by interleukin (IL)-10 and IL-12. Vet Immunol Immunopathol 2004, 102:67-76.

21. Pedersen $L G$, Castelruiz $Y$, Jacobsen $S$, Aasted B: Identification of monoclonal antibodies that cross-react with cytokines from different animal species. Vet Immunol Immunopathol 2002, 88:111-122.

22. Kwong LS, Hope JC, Thom ML, Sopp P, Duggan S, Bembridge GP, Howard CJ: Development of an ELISA for bovine IL-10. Vet Immunol Immunopathol 2002, 85:213-223.

23. La Bonnardière $C$, Lefèvre $F$, Charley B: Interferon response in pigs: molecular and biological aspects. Vet Immunol Immunopathol 1994, 43:29-36.

24. Bonneau M, Epardaud M, Payot F, Niborski V, Thoulouze Ml, Bernex F, Charley B, Riffault S, Guilloteau LA, Schwartz-Cornil I: Migratory monocytes and granulocytes are major lymphatic carriers of Salmonella from tissue to draining lymph node. J Leukoc Biol 2006, 79:268-276.

25. Bouskra D, Brézillon C, Bérard M, Werts C, Varona R, Boneca IG, Eberl G: Lymphoid tissue genesis induced by commensals through NOD1 regulates intestinal homeostasis. Nature 2008, 456:507-510.

26. Fach SJ, Brockmeier SL, Hobbs LA, Lehmkuhl HD, Sacco RE: Pulmonary dendritic cells isolated from neonatal and adult ovine lung tissue. Ve Immunol Immunopathol 2006, 112:171-182.

27. Foulon E, Foucras G: Two populations of ovine bone marrow-derived dendritic cells can be generated with recombinant GM-CSF and separated on CD11b expression. J Immunol Methods 2008, 339:1-10.

28. Booth JS, Griebel PJ, Babiuk LA, Mutwiri GK: A novel regulatory B-cell population in sheep Peyer's patches spontaneously secretes IL-10 and downregulates TLR9-induced IFNalpha responses. Mucosal Immunol 2009, 2:265-275

29. Byrnes AA, Ma X, Cuomo P, Park K, Wahl L, Wolf SF, Zhou H, Trinchieri G, Karp CL: Type I interferons and IL-12: convergence and cross-regulation among mediators of cellular immunity. Eur J Immunol 2001, 31:2026-2034.

30. Gautier G, Humbert M, Deauvieau F, Scuiller M, Hiscott J, Bates EE, Trinchieri G, Caux C, Garrone P: A type I interferon autocrine-paracrine loop is involved in Toll-like receptor-induced interleukin-12p70 secretion by dendritic cells. J Exp Med 2005, 201:1435-1446.

31. Rothenfusser S, Tuma E, Endres S, Hartmann G: Plasmacytoid dendritic cells: the key to CpG. Hum Immunol 2002, 63:1111-1119.

32. Kuwajima S, Sato T, Ishida K, Tada H, Tezuka HTO: Interleukin 15dependent crosstalk between conventional and plasmacytoid dendritic cells is essential for CpG-induced immune activation. Nat Immunol 2006 7:740-746

33. Klinman DM: Use of CpG oligodeoxynucleotides as immunoprotective agents. Expert Opin Biol Ther 2004, 4:937-946.

34. Kwissa M, Amara RR, Robinson HL, Moss B, Alkan S, Jabbar A, Villinger $F$ Pulendran B: Adjuvanting a DNA vaccine with a TLR9 ligand plus Flt3 ligand results in enhanced cellular immunity against the simian immunodeficiency virus. J Exp Med 2007, 204:2733-2746.

35. Krieg AM: Toll-like receptor 9 (TLR9) agonists in the treatment of cancer. Oncogene 2008, 27:161-167

36. Chelvarajan L, Popa D, Liu Y, Getchell TV, Stromberg AJ, Bondada S: Molecular mechanims underlying anti-inflammatory phenotype of neonatal splenic macrophages. J Leukoc Biol 2007, 82:403-416.

37. Kollmann TR, Crabtree J, Rein-Weston A, Blimkie D, Thommai F, Wang XY, Lavoie PM, Furlong J, Fortuno ESr, Hajiar AM, Hawkins NR, Self SG Wilson CB: Neonatal innate TLR-mediated responses are distinct from those of adults. J Immunol 2009, 183:7150-7160

38. Nguyen $M$, Leuridan $E$, Zhang $T$, De Wit D, Willems F, Van Damme $P$, Goldman M, Goriely S: Acquisition of adult-like TLR4 and TLR9 responses during the first year of life. PLOS One 2010, 5:e10407.

39. Nakano H, Lin KL, Yanagita M, Charbonneau C, Cook DN, Kakiuchi T, Gunn MD: Blood-derived inflammatory dendritic cells in lymph nodes stimulate acute T helper type 1 immune responses. Nat Immunol 2009, 10:394-402.

40. Price SJ, Hope JC: Enhanced secretion of interferon-gamma by bovine gammadelta $T$ cells induced by coculture with Mycobacterium bovisinfected dendritic cells: evidence for reciprocal activating signals. Immunology 2009, 126:201-208.

41. Hedges JF, Lubick KJ, Jutila MA: Gamma delta T cells respond directly to pathogen-associated molecular patterns. J Immunol 2005, 174:6045-6053. 
42. Pulendran B: Division of labor and cooperation between dendritic cells. Nat Immunol 2006, 7:699-700

doi:10.1186/1297-9716-42-19

Cite this article as: Ferret-Bernard et al: Mesenteric lymph node cells

from neonates present a prominent IL-12 response to CpG

oligodeoxynucleotide via an IL-15 feedback loop of amplification.

Veterinary Research 2011 42:19.

Submit your next manuscript to BioMed Central and take full advantage of:

- Convenient online submission

- Thorough peer review

- No space constraints or color figure charges

- Immediate publication on acceptance

- Inclusion in PubMed, CAS, Scopus and Google Scholar

- Research which is freely available for redistribution

Submit your manuscript at 